\title{
Lip and Oral Cavity Cancer pT4b TNM Finding v6
}

National Cancer Institute

\section{Source}

National Cancer Institute. Lip and Oral Cavity Cancer pT 4b TNM Finding v6. NCI

Thesaurus. Code C64416.

Lip and oral cavity cancer with tumor involving the masticator space, pterygoid plates, or skull base and/or encases the internal carotid artery. (from AJCC 6th Ed.) 